\title{
Pengaruh Komitmen Organisasi dan Motivasi Kerja Terhadap Kinerja Auditor Dengan Tindakan Supervisi Sebagai Variabel Moderasi
}

\author{
Ida Ayu Mirah Kusuma Putri ${ }^{1}$ \\ I Dewa Nyoman Badera ${ }^{2}$ \\ ${ }^{1,2}$ Fakultas Ekonomi dan Bisnis Universitas Udayana (Unud), Bali, Indonesia \\ e-mail: mirahkusumap@gmail.com
}

\begin{abstract}
ABSTRAK
Dalam melaksanakan tugasnya sebagai seorang akuntan publik, auditor dituntut untuk bekerja sesuai pedoman standar audit dan kode etik akuntan. Kinerja audit dipengaruhi oleh beberapa faktor yaitu diantaranya komitmen organisasi, motivasi kerja dan tindakan supervisi. Penelitian ini bertujuan untuk mengetahui pengaruh komitmen organisasi dan motivasi kerja terhadap kinerja auditor dengan tindakan supervisi sebagai variabel moderasi. Lokasi penelitian ini dilakukan di Kantor Akuntan Publik di Provinsi Bali. Data penelitian ini menggunakan data primer yang diolah melalui penyebaran kuesioner dengan teknik analisis data menggunakan analisis regresi moderasi. Hasil penelitian ini menunjukkan bahwa komitmen organisasi dan motivasi kerja berpengaruh positif dan signifikan terhadap kinerja auditor. Hasil penelitian juga menunjukkan bahwa tindakan supervisi memperkuat hubungan komitmen organisasi maupun motivasi kerja terhadap kinerja auditor di Kantor Akuntan Publik Provinsi Bali.
\end{abstract}

Kata kunci: Komitmen organisasi, motivasi kerja, tindakan supervisi dan kinerja auditor

\begin{abstract}
In carrying out its duties as a public accountant, auditors are required to work in accordance with audit standard guidelines and accountants' code of ethics. Audit performance is influenced by several factors, including organizational commitment, work motivation and supervision measures. This study aims to determine the effect of organizational commitment and work motivation on the performance of auditors with supervision as a moderating variable. The location of this research was conducted at the Public Accountant Office in the Province of Bali. The data of this study uses primary data processed through questionnaires with data analysis techniques using moderation regression analysis. The results of this study indicate that organizational commitment and work motivation have a positive and significant effect on auditor performance. The results of the study also show that supervision measures strengthen the relationship between organizational commitment and work motivation towards auditor performance at the Bali Provincial Public Accountant Office.

Keywords: Organizational commitment, work motivation, supervision actions and auditor performance
\end{abstract}

\section{PENDAHULUAN}

Berkembangnya dunia bisnis pada zaman sekarang ini banyak pelaku bisnis yang akan membuat laporan keuangan untuk mengetahui posisi keuangan dan hasil usahanya sebagai acuan untuk pengambilan keputusan. Dunia bisnis yang 
Ida Ayu Mirah Kusuma Putri dan I Dewa Nyoman Badera. Pengaruh...

mengalami perkembangan pesat akan membuka peluang bagi Kantor Akuntan Publik untuk menyediakan jasa. Perubahan pesat yang terjadi di lingkungan bisnis pada era sekarang ini, menuntut akuntan publik untuk meningkatkan mutu jasa audit atas laporan jasa keungan historis, jasa atestasi, dan jasa akuntansi dan review (Jusup, 2014). Kantor Akuntan Publik merupakan sebuah organisasi yang bergerak di bidang jasa. Akuntan Publik dalam menjalankan profesinya di atur oleh kode etik profesi. Profesi seorang akuntan publik memegang peranan yang sangat penting dalam perkembangan bisnis global saat ini. Pentingnya peran profesi akuntan publik adalah untuk meningkatkan kualitas informasi keuangan atau laporan keuangan suatu entitas.

Profesi akuntan mempunyai peran penting dalam penyediaan informasi keuangan yang handal bagi pemerintah, pemegang saham, investor, kreditor, debitur, karyawan, masyarakat dan pihak-pihak lain yang berkepentingan (Sagung Dea, 2018). Maka banyak perusahaan yang membutuhkan jasa untuk melakukan pemeriksaan. Auditor merupakan salah satu jasa yang melakukan pemeriksaan tersebut. Tugas seorang auditor tersebut disebut dengan auditing. Auditing adalah suatu proses sistematis untuk memperoleh dan mengevaluasi bukti yang berhubungan dengan asersi tentang tindakan-tindakan dan kejadian ekonomi secara obyektif untuk menentukan tingkat kepatuhan antara asersi tersebut dengan kriteria yang telah ditetapkan dan mengomunikasikan hasilnya kepada pihakpihak yang berkepentingan (Jusup, 2014).

Pentingnya laporan keuangan dalam perusahaan untuk proses pengambilan keputusan menyebabkan kebutuhan jasa akuntan semakin berkembang. Pada era 
sekarang ini banyak Kantor Akuntan Publik (KAP) telah memiliki izin usaha, hal tersebut menyebabkan persaingan auditor pun semakin pesat. Auditor yang profesional, tekun, teliti dan memiliki kinerja yang baik menjadi pertimbangan utama klien dalam mencari rekan bisnis dalam pembuatan laporan keuangan. Hal tersebut menuntut auditor untuk memiliki integritas dan objektivitas demi menjaga kepercayaan klien. Auditor dituntut memiliki kinerja yang baik yang sesuai dengan pemahaman atas SPAP, SAK, kode etik, dan standar mutu dan mampu meyakinkan ke semua pengguna informasi fakta dari hasil pemeriksaan tersebut.

Kasus KAP Andersen dan Enron pada tahun 2001 yang terungkap saat Enron medaftarkan kebangkrutannya ke pengadilan. Terdapat hutang perusahaan yang tidak dilaporkan yang menyebabkan nilai investasi dan laba yang ditahan berkurang dalam jumlah sama. Sebelum kebangkrutan Enron terungkap, KAP Andersen mempertahankan Enron sebagai klien perusahaan, dengan memanipulasi laporan keuangan dan penghancuran dokumen atas kebangkrutan Enron. KAP Andersen terus menerima konsekwensi negatif dari kasus Enron berupa kehilangan klien, pembelotan afiliasi dan pengungkapan yang meningkat mengenai keterlibatan pegawai KAP Andersen dalam kasus Enron. Mantan ketua Federal Reserve, Paul Volkcer yang direkrut untuk melakukan revisi terhadap praktek audit dan dapat memperbaiki citra KAP Andersen mengusulkan agar manjemen KAP Andersen yang ada diberhentikan dan membentuk komite baru yang diketua oleh Paul sendiri. Didirikannya manajemen baru pada KAP Andersen juga tidak dapat mengembalikan citra KAP Andersen dimata publik. 
Ida Ayu Mirah Kusuma Putri dan I Dewa Nyoman Badera. Pengaruh...

Karena kasus Enron izin KAP Arthur Andersen dicabut oleh Otoritas Keuangan Amerika Serikat.

Banyaknya kasus-kasus yang terjadi pada Kantor Akuntan Publik terjadi karena kurangnya tanggungjawab seorang auditor dan kesadarannya tentang etika profesi seorang akuntan maupun supervisor yang kurang aktif berperan dalam pemberian bimbingan dan pengawasan terhadap asisten dan akuntan pemula yang menyebabkan adanya ketidaksamaan persepsi dalam pelaporan keuangan sehingga menimbulkan adanya manipulasi laporan keuangan dalam kasus Enron. Kasus tersebut membuktikan masih belum maksimalnya kinerja auditor karena peran seorang auditor belum optimal.

Permasalahan yang sering terjadi mengenai auditor menjadi perhatian utama dalam dunia bisnis. Banyaknya kasus-kasus tentang akuntan publik seperti kasus KAP Andersen, terutama mengenai penyelesaian tanggung jawabnya, menyebabkan lembaga penyusun standar akuntansi untuk menyusun kembali peraturan-peraturan mengenai tugas dan tanggung jawab auditor dengan baik. Untuk menuju akuntan publik yang profesional, tantangan yang harus dihadapi yaitu pemahaman atas SPAP, SAK, kode etik, dan standar mutu. Selain itu asosiasi profesi akuntan publik juga harus menghadapi tantangan seperti penerapan standar profesi yang benar serta peningkatan kualitas sertifikasi profesi, sehingga dihasilkan akuntan publik yang kompeten dan professional. Hal tersebut dilakukan untuk dapat menghasilkan kinerja auditor yang baik dan menjadi auditor yang handal dan dipercaya oleh klien. 
Kinerja merupakan hasil kerja yang dicapai seseorang dalam melaksanakan tugas sesuai dengan tanggung jawab yang diberikan (Kalbers \& Fogarty, 1995). Kinerja auditor merupakan tindakan atau pelaksanaan tugas pemeriksaan yang telah diselesaikan oleh auditor dalam kurun waktu tertentu. Pengertian kinerja auditor adalah hasil kerja yang dicapai oleh auditor dalam melaksanakan tugasnya, sesuai dengan tanggung jawab yang diberikan kepadanya dan menjadi salah satu tolak ukur yang digunakan untuk menentukan apakah suatu pekerjaan yang dilakukan akan baik atau sebaliknya. Menurut (Dali \& Mas'ud, 2014) kinerja auditor adalah kemampuan seorang auditor dalam menghasilkan temuan dari tugasnya dalam kegiatan pemeriksaan. Kinerja auditor menjadi perhatian utama, bagi klien ataupun publik dalam menilai hasil audit yang dilakukan (Fanani et al., 2008). (Al-khaddash et al., 2013) mengatakan bahwa untuk menunjang keberhasilan dalam menjalankan tugas dan fungsinya dengan baik, kinerja auditor yang baik dan berkualitas sangat diperlukan. Dalam mengukur kinerja auditor, menurut (Larkin, 1990) terdapat empat dimensi personalitas, yaitu kemampuan (ability), komitmen profesional, motivasi, dan kepuasan kerja. Menurut (Goldwasser, 1993) pencapaian suatu kinerja atau prestasi kerja seorang auditor dapat dinilai dari tiga indikator yaitu: kualitas pekerjaan, kuantitas pekerjaan, dan ketepatan waktu. Auditor yang komitmen terhadap profesinya maka akan loyal terhadap profesinya seperti yang dipersepsikan oleh auditor tersebut. Kepuasan kerja auditor adalah tingkat kepuasan individu auditor dengan posisinya dalam organisasi secara relatif dibandingkan dengan teman sekerja atau teman seprofesi lainnya. Adapun hal-hal 
Ida Ayu Mirah Kusuma Putri dan I Dewa Nyoman Badera. Pengaruh...

yang dapat mempengaruhi kinerja auditor seperti komitmen organisasi dan motivasi kerja. Banyaknya tugas seorang auditor yang bervariasi dan memiliki tingkat kesulitan yang lebih tinggi menuntut auditor untuk memiliki komitmen organisasi dan motivasi kerja yang tinggi agar kinerjanya dalam menyelesaikan tugas tersebut baik.

Faktor yang mempengaruhi kinerja auditor adalah komitmen organisasi dan motivasi kerja. Komitmen organisasi merupakan tingkat loyalitas seseorang terhadap organisasi tempatnya bekerja sehingga organisasi dapat berjalan sesuai dengan tujuannya (Sari Kartika, 2016). Menurut Robbins (2008) keterlibatan seseorang dalam suatu pekerjaan berarti menunjukkan bahwa seseorang tersebu berpihak pada pekerjaannya sehingga komitmen pada organisasi diartikan sejauh mana seorang karyawan memihak pada suatu organisasi tertentu dan tujuantujuannya, serta berniat memelihara keanggotaan dalam organisasi tersebut. Komitmen organisasi merupakan kekuatan individu yang didefinisikan dan dikaitkan dengan bagian organisasi. Komitmen terhadap organisasi menunjukkan suatu keadaan dimana karyawan atau auditor mempunyai nilai dan tujuan yang sama dengan organisasi Kantor Akuntan Publik (KAP), terlibat dalam pencapaian tujuan organisasi serta berniat memelihara keanggotaan dalam organisasi (Aranya, Nissim and Ferris, n.d.).

Auditor seringkali harus menghadapi berbagai macam tekanan dari pihak manajemen ataupun dari pihak pemakai informasi keuangan lainnya yang dapat mempengaruhi kualitas opini auditor di dalam pelaksanaan peran, tugas dan tanggung jawabnya (Knapp, 1985: Carcllo \& Neal, 2000). Melalui peran, tugas 
dan tanggung jawabnya tersebut dapat dilihat sejauh mana auditor mampu dalam menjalani hal tersebut. Hal inilah yang disebut dengan komitmen organisasi, yaitu kekuatan seseorang individu yang berkaitan dengan organisasi dan memiliki tanggungjawab terhadap hal tersebut.

Dalam penelitian (Lawalata et al., 2010) menyatakan bahwa komitmen organisasi memiliki pengaruh positif terhadap kinerja auditor. Penelitian Riezki (2015) juga menyatakan bahwa komitmen organisasi berpengaruh terhadap kinerja auditor. Penelitian (Trisnaningsih, 2007), Wibowo (2009), Wijana (2015), Putri (2015), Alfianto dan Suryandari (2015) dan Agustini (2017) menyatakan komitmen organisasi berpengaruh positif dan signifikan terhadap kinerja auditor. Hal ini bertentangan dengan penelitian yang dilakukan oleh (Hanna \& Firnanti, 2013), Gummala (2006) dan Siahaan (2010) yang menyatakan bahwa komitmen organisasi tidak berpengaruh terhadap kinerja auditor.

Faktor lain yang mempengaruhi kinerja auditor yaitu motivasi kerja. Motivasi kerja merupakan proses atau faktor yang mendorong orang untuk bertindak atau berperilaku dengan cara tertentu. Kemampuan seseorang yang dibarengi dengan motivasi yang tinggi akan menghasilkan kinerja yang baik. Kinerja yang baik akan sangat berpengaruh terhadap tingkat pencapaian tujuan organisasi. Menurut Robbins dan Judge (2007: 214) motivasi diartikan sebagai kesediaan untuk melaksanakan upaya tinggi untuk mencapai tujuan-tujuan keorganisasian, yang dikondisikan oleh kemampuan upaya untuk memenuhi individual tertentu. Edwin B. Flippo dalam Hasibuan (2007: 163) mengatakan indikator motivasi kerja yaitu: upah yang layak, kesempatan untuk maju, promosi, 
Ida Ayu Mirah Kusuma Putri dan I Dewa Nyoman Badera. Pengaruh...

pengakuan sebagai individu, keamanan, tempat kerja yang baik, penerimaan oleh kelompok, perlakuan yang wajar, dan pengakuan atas prestasi. Motivasi penting karena dengan motivasi diharapkan setiap individu bekerja keras dan antusias untuk mencapai hasil kerja yang tinggi. Motivasi kerja secara umum dapat diidentifikasi sebagai serangkaian kekuatan penggerak yang muncul dari dalam dan diluar diri masing-masing individu. Kedua kekuatan itu menimbulkan minat kerja dan berhubungan dengan tingkah laku dan menentukan arah, intensitas dan durasi dari tingkah laku atau kebiasaan individual (Hasibuan, 2001).

Penelitian Daryatmi (2005) menyatakan bahwa motivasi mempunyai pengaruh positif dan signifikan terhadap produktifitas karyawan. Penelitian Syamsul (2010) menyatakan bahwa motivasi berpengaruh positif terhadap kinerja auditor. Penelitian Dalmy (2009) menyatakan bahwa motivasi kerja memiliki pengaruh signifikan terhadap kinerja auditor. Penelitian Albar (2009) membuktikan bahwa motivasi kerja berpengaruh terhadap kinerja auditor. Penelitian Dwilita (2007) membuktikan bahwa motivasi kerja berpengaruh terhadap kinerja auditor. Namun Penelitian Siregar (2012) menyatakan bahwa motivasi kerja tidak berpengaruh terhadap kinerja auditor.

Penelitian dikatakan tidak konsisten karena ditemukannya hasil penelitian yang berbeda terkait pengaruh satu variabel dengan variabel lainnya, sehingga masih perlu dikonfirmasi. Cara untuk merekonsiliasi hasil yang bertentangan tersebut adalah meneliti berbagai faktor kondisional yang bertindak sebagai variabel moderasi (Murray, 1990) dengan pendekatan kontijensi (Govindarajan, 1986) dalam (Agustini, 2017). Pendekatan kontijensi (contingency approach) 
dilakukan dengan mengevaluasi berbagai faktor kondisional yang mempengaruhi kinerja. Dasar pendekatan kontijensi adalah tidak adanya rancangan atau sistem akuntansi yang dapat diterapkan secara efektif untuk semua kondisi organisasi. Akibat ketidakkonsistenan pada hasil penelitian sebelumnya, maka penelitian ini menggunakan pendekatan kontijensi dengan memasukkan variabel moderasi. Variabel moderasi yang digunakan pada penelitian ini yaitu tindakan supervisi.

Kasus yang sering terjadi juga disebabkan oleh tuntutan-tuntutan para pemakai laporan keuangan yang merasa bahwa auditor tidak melakukan tugasnya dengan baik. Masalah yang terjadi pada Kantor Akuntan Publik seringkali disebabkan oleh asisten dan akuntan pemula atau akuntan publik yang belum professional sebagai pihak yang harus disupervisi mengalami ketidaksamaan persepsi karena keberadaan supervisor yang kurang aktif berperan dalam pemberian bimbingan dan pengawasan. Kurangnya pemberian umpan balik, rendahnya kesempatan untuk berpartisipasi dan kurangnya pujian untuk pekerjaan yang dilakukan dengan baik juga merupakan penyebab munculnya ketidaksamaan persepsi tersebut. Situasi seperti ini dibutuhkan peningkatan standar mutu dan kompetensi yang dimiliki melalui adanya tindakan supervisi yang dapat menjadi pedoman bagi auditor dalam pengambilan keputusan penugasan audit.

Menurut BPK RI (2009:73) supervisi mencakup pengarahan kegiatan pemeriksa dan pihak lain (seperti tenaga ahli yang terlibat dalam pemeriksaan) agar pemeriksaan dapat dicapai. Unsur supervisi meliputi pemberian instruksi kepada staf, pemberian informasi mutakhir tentang masalah signifikan yang dihadapi, pelaksanaan review atas pekerjaan yang dilakukan, dan pemberian kerja 
Ida Ayu Mirah Kusuma Putri dan I Dewa Nyoman Badera. Pengaruh...

lapangan (on the job training) yang efektif. Supervisi merupakan hal yang penting, sesuai dengan kutipan AECC (Accounting Education Change Commission) dalam Martamin (2006:17), AECC telah menerbitkan Issue Statement No. 4 yang berisi AECC Reccomendations Early Work Experience yang mendorong pemberdayaan akuntan melalui tindakan supervisi yang tepat akan menumbuhkan instrinsik motivation. Adanya tindakan supervisi dan tumbuhnya motivasi kerja sangat menentukan prestasi kerja (kinerja). Larkin dan Schweikart dalam Chandra (2006) kinerja seringkali identik dengan kemampuan (ability) seorang auditor bahkan berhubungan dengan komitmen terhadap profesi.

Tindakan supervisi merupakan salah satu faktor yang mampu dalam menyelesaikan persoalan yang kompleks dan rumit. Peranan supervisi ini meliputi pemeriksaan pekerjaan, pemberian saran dan bimbingan sebagai umpan balik bagi bawahan, dan memberikan dukungan mental bagi bawahan. Supervisi termasuk dalam standar pekerjaan lapangan yang menekankan bahwa pekerjaan harus direncanakan dengan baik, dan jika digunakan asisten, harus disupervisi dengan benar. Supervisor yang efektif dapat membantu menciptakan lingkungan kerja yang dapat menimbulkan tingkat kepuasan kerja yang tinggi bagi para karyawan atau staf (Agustini, 2017). Supervisor yang dapat memotivasi bawahannya dan mempengaruhi bawahannya agar memiliki komitmen yang tinggi dapat menghasilkan kinerja audit yang baik dan menghasilkan hasil audit yang relevan, kompeten, material dan cukup adalah cermin kinerja audit yang baik.

Teori atribusi menjelaskan tentang cara kita menilai individu secara berbeda, kita berupaya untuk menentukan apakah perilaku tersebut disebabkan 
secara internal atau eksternal. Perilaku yang dipengaruhi secara internal adalah perilaku dari dalam kendali pribadi individu itu sendiri sedangkan eksternal adalah perilaku yang disebabkan oleh sebab-sebab luar (Robbins, 2015:117).

Atribusi internal maupun eksternal telah dinyatakan dapat mempengaruhi sikap dan kepuasan individu terhadap kinerja. Orang akan berbeda perilakunya jika mereka lebih merasakan atribut internalnya daripada eksternalnya (Agustini, 2017). Seseorang akan membentuk ide tentang orang lain dan situasi disekitarnya yang menyebabkan perilaku seseoang dengan kondisi disekitarnya yang disebut dengan dispositional attributions dan situational attributions. Dispositional attributions atau penyebab internal yaitu aspek perilaku dalam diri seseorang seperti kepribadian, persepsi diri, kemampuan, dan motivasi. Sedangkan situational attributions atau penyebab eksternal yang mengacu pada lingkungan sekitar yang dapat mempengaruhi perilaku seperti kondisi social, nilai-nilai social, dan pandangan masyarakat.

Karakteristik personal seorang auditor merupakan salah satu penentu terhadap kualitas audit yang dilakukan karena merupakan faktor internal yang mendorong seseorang untuk melakukan suatu aktivitas (Ariati, 2004). Atribusi personal juga meliputi tindakan supervisi auditor yang dapat digunakan untuk memecahkan masalah, karena tindakan supervisi melakukan pengawasan secara langsung dan berkala oleh atasan terhadap pekerjaan yang dilaksanakan oleh bawahan dan dapat memberikan petunjuk atau bantuan langsung dalam mengatasi permasalahan apabila ditemukan masalah. 
Ida Ayu Mirah Kusuma Putri dan I Dewa Nyoman Badera. Pengaruh...

Peneliti menggunakan teori atribusi karena peneliti akan melakukan penelitian mengenai faktor-faktor yang dapat mempengaruhi kinerja auditor, khususnya pada karakteristik pribadi auditor itu sendiri. Karakteristik pribadi merupakan salah satu penentu kinerja seorang auditor dalam melaksanakan pekerjaannya.

Komitmen merupakan suatu konsistensi diri dari wujud keterikatan seseorang terhadap suatu hal atau pekerjaan, misalnya seperti: karir, pekerjaan, organisasi, lingkungan dan sebagainya. Melalui adanya suatu komitmen organisasi ini dapat menjadi dorongan bagi auditor untuk bekerja lebih baik sehingga dapat meningkatkan kinerjanya. Dalam hasil penelitian Tahir dan Monil (2014) manyatakan bahwa prestasi kerja karyawan memberikan patokan bagi organisasi untuk dapat memberikan layanan yang lebih baik karena komitmen organisasi mempengaurhi kinerja karyawan secara positif. Dilihat dari penelitian sebelumnya yaitu penelitian Fernando et al (2005), (Lawalata et al, 2010), Riezki (2015), Wijana (2015), Putri (2015), Alfianto et al (2015) dan (Agustini, 2017) menyatakan bahwa komitmen organisasi berpengaruh positif dan signifikan terhadap kinerja auditor. Hal ini bertentangan dengan penelitian yang dilakukan oleh Somers et al (1998), (Hanna \& Firnanti, 2013) dan (Siahaan, 2010) yang menyatakan bahwa komitmen organisasi tidak berpengaruh terhadap kinerja auditor.

$\mathrm{H}_{1}$ : Komitmen Organisasi berpengaruh positif terhadap kinerja auditor.

Motivasi kerja merupakan suatu dorongan perilaku individu untuk bekerja keras dan antusias dan mengeluarkan tingkat upaya yang tinggi untuk mencapai 
hasil kerja yang tinggi demi tujuan suatu organisasi. Motivasi sangat diperlukan seorang auditor karena perilaku tersebut dapat menumbuhkan semangat tinggi dalam mengejarkan tugas-tugas auditor tersebut demi tercapainya kinerja auditor yang baik dan terwujudnya tujuan dari organisasi. Menurut penelitian yang telah dilakukan oleh Daryatmi (2005), (Bahri, 2010), (Dalmy, 2009), (Akbar, 2009) dan Dwilita (2007) membuktikan bahwa motivasi kerja berpengaruh positif dan signifikan terhadap kinerja auditor. Hal ini bertentangan dengan penelitian Siregar (2012) yang menyatakan bahwa motivasi kerja tidak berpengaruh terhadap kinerja auditor karena tanggung jawab yang begitu besar belum sebanding menurut sebagian besar pemeriksa sehinga motivasi untuk memperoleh jabatan dan tambahan tunjangan belum berpengaruh terhadap kinerja auditor.

Berdasarkan uraian di atas dan hasil penelitian sebelumnya dapat dirumuskan hipotesis:

$\mathrm{H}_{2}$ : Motivasi Kerja berpengaruh positif terhadap kinerja auditor.

Tindakan supervisi merupakan tindakan yang dapat mempengaruhi individu maupun organisasi dalam melaksanakan tugas-tugasnya. Melalui adanya saran-saran pelaksanaan tindakan supervisi yang terdapat dalam AECC (Accounting Education Change Commission) dapat memberikan bagaimana peran supervisor yang baik bagi bawahannya. Seorang supervisor yang dapat menumbuhkan hubungan yang baik antara atasan dan bawahannya akan mendorong tercapainya kesuksesan. Seorang individu atau sekelompok orang yang memiliki komitmen organisasi yang tinggi akan memberikan hasil kinerja yang baik guna tercapainya tujuan dari organisasi itu sendiri. Pada dasarnya 
Ida Ayu Mirah Kusuma Putri dan I Dewa Nyoman Badera. Pengaruh...

komitmen organisasi itu adalah suatu keadaan yang menunjukkan bahwa seorang auditor memiliki hubungan baik dengan organisasi itu melalui adanya tujuan yang sama dengan organisasi tersebut dan adanya hubungan yang baik antara supervisor dan bawahannya (Agustini, 2017).

$\mathrm{H}_{3}$ : Tindakan Supervisi memperkuat hubungan antara komitmen organisasi terhadap kinerja auditor.

Seorang supervisor yang dapat mempengaruhi bawahannya dengan memberikan feedback, memberikan masukan-masukan, mengevaluasi pekerjaan karyawan secara fair (adil) dan dapat menerima segala keluh kesah bawahannya maka dapat memberikan kesan baik kepada karyawan untuk memberikan hasil kerja yang maksimal. Seperti yang terdapat dalam AECC bahwa peran seorang auditor adalah dapat menunjukkan sikap kepemimpinan dan mentoring yang kuat karena melalui hal tersebut diharapkan dapat memotivasi kerja seorang auditor agar dapat menghasilkan kinerja yang baik. Motivasi kerja itu sendiri sangat penting bagi seorang auditor untuk meningkatkan kinerjanya karena perilaku tersebut dapat menumbuhkan semangat tinggi dan antusiasme dalam mengejarkan tugas-tugas auditor tersebut demi tercapainya kinerja auditor yang baik dan terwujudnya tujuan dari organisasi (Siregar, 2012)

$\mathrm{H}_{4}$ : Tindakan Supervisi memperkuat hubungan antara motivasi kerja terhadap kinerja auditor.

\section{METODE PENELITIAN}

Penelitian ini dilakukan pada Kantor Akuntan Publik yang terdapat di Bali dan terdaftar pada Institut Akuntan Publik Indonesia. Populasi dalam penelitian ini adalah seluruh auditor yang bekerja pada Kantor Akuntan Publik yang terdaftar di 
IAPI wilayah Bali. Dengan demikian populasi pada penelitian ini dapat dilihat pada tabel 1 .

\section{Tabel 1.}

Daftar Jumlah Auditor pada Kantor Akuntan Publik di Bali Tahun 2018

\begin{tabular}{clc}
\hline No & \multicolumn{1}{c}{ Nama Kantor Akuntan Publik } & Jumlah Auditor \\
\hline 1 & KAP I Wayan Ramantha & 7 \\
2 & KAP Johan Malonda Mustika \& Rekan (Cab) & 10 \\
3 & KAP K. Gunarsa & 12 \\
4 & KAP Drs. Ketut Budiartha, M.Si & 10 \\
5 & KAP Drs. Sri Marmo Djogosarkono \& Rekan & 17 \\
6 & KAP Drs. Ketut Muliartha RM \& Rekan & 7 \\
7 & KAP Drs. Wayan Sunasdyana & 2 \\
8 & KAP Arnaya \& Darmayasa & 6 \\
9 & KAP Budhananda Munidewi & Total \\
\end{tabular}

Sumber: Data diolah, 2018

Penelitian ini menggunakan teknik non probability sampling dengan teknik sampel jenuh. Berdasarkan metode tersebut, maka seluruh populasi akan menjadi sampel yaitu sebanyak 77 auditor.

Penelitian ini menggunakan MRA karena dapat menjelaskan pengaruh variabel moderasi dalam memperkuat atau memperlemah hubungan antara variabel independen dengan dependen. Adapun persamaan regresi yang dihasilkan dari regresi moderasi dalam penelitian ini adalah:

$$
Y=\alpha+\beta_{1} X_{1}+\beta_{2} X_{2}+\beta_{3} X_{3}+\beta_{3}\left(X_{1} X_{3}\right)+\beta_{4}\left(X_{2} X_{3}\right)+e
$$

Keterangan :

$\mathrm{Y} \quad=$ Kinerja auditor

$\mathrm{a} \quad=$ Konstanta

$\mathrm{X}_{1} \quad=$ Komitmen Organisasi

$\mathrm{X}_{2} \quad=$ Motivasi Kerja

$\mathrm{X}_{3} \quad=$ Tindakan supervisi

$\beta_{1}-\beta_{4}=$ Koefisien regresi masing-masing faktor

$\mathrm{X}_{1} \mathrm{X}_{3}=$ Interaksi komitmen organisasi dengan tindakan supervisi

$\mathrm{X}_{2} \mathrm{X}_{3}=$ Interaksi motivasi kerja dengan tindakan supervisi

$e \quad=$ Standar error 
Ida Ayu Mirah Kusuma Putri dan I Dewa Nyoman Badera. Pengaruh...

\section{HASIL DAN PENELITIAN}

Statistik deskriptif menyajikan informasi mengenai karakteristik variable-variabel penelitian yaitu jumlah amatan, nilai minimum, nilai maksimum, nilai mean dan standar deviasi. Untuk mengukur nilai sentra dari distribusi data dapat dilakukan dengan pengukuran rata-rata (mean) sedangkan standar deviasi merupakan perbedaan nilai data yang diteliti dengan nilai rata-ratanya. Hasil statistik deskriptif dapat dilihat pada Tabel 2.

Tabel 2.

Hasil Statistik Deskriptif

\begin{tabular}{clccccc}
\hline No & \multicolumn{1}{c}{ Variabel } & N & Minimum & Maximum & Mean & Std Deviation \\
\hline 1 & Komitmen Organisasi (X1) & 48 & 3,00 & 5,00 & 4,38 & 0,49 \\
2 & Motivasi Kerja (X2) & 48 & 3,00 & 5,00 & 4,16 & 0,53 \\
3 & Tindakan Supervisi (X3) & 48 & 3,20 & 5,00 & 4,14 & 0,42 \\
4 & Kinerja Auditor (Y) & 48 & 3,20 & 5,00 & 4,11 & 0,46 \\
\hline
\end{tabular}

Sumber: Data diolah, 2018

Berdasarkan Tabel 2 dapat disimpulkan bahwa jumlah kuesioner (N) penelitian ini berjumlah 48. Variabel komitmen organisasi memiliki nilai minimum sebesar 3,00 dan nilai maksimum sebesar 5,00 dengan nilai rata-rata sebesar 4,38. Nilai rata-rata sebesar 4,38 menunjukkan bahwa responden dalam menjawab pernyataan pada kuesioner cenderung merasa setuju, artinya komitmen auditor sudah tinggi dalam menjalankan tugasnya sebagai seorang auditor. Standar deviasi pada variable komitmen organisasi adalah 0,49. Hal ini menunjukkan bahwa standar penyimpangan data terhadap nilai rata-ratanya adalah 0,49 .

Variable motivasi kerja memiliki nilai minimum sebesar 3,00 dan nilai maksimum sebesar 5,00 dengan nilai rata-rata sebesar 4,16. Nilai rata-rata sebesar 
4,16 menunjukkan bahwa respon responden dalam menjawab pernyataan pada kuesioner cenderung merasa setuju, artinya motivasi kerja auditor tinggi dalam melaksanakan tugasnya. Standar deviasi pada variable motivasi kerja adalah sebesar 0,53. Hal ini menunjukkan bahwa standar penyimpangan data terhadap nilai rata-ratanya adalah 0,53 .

Variabel tindakan supervisi memiliki nilai minimum sebesar 3,20 dan nilai maksimum sebesar 5,00 dengan nilai rata-rata sebesar 4,14. Nilai rata-rata sebesar 4,14 menunjukkan bahwa respon responden dalam menjawab pernyataan pada kuesioner cenderung merasa setuju, artinya supervisor telah menjalankan perannya dalam mengawasi dan mengendalikan pelaksanaan pekerjaan bawahannya. Standar deviasi pada variable tindakan supervise adalah sebesar 0,42. Hal ini menunjukkan bahwa standar penyimpangan data terhadap nilai ratarata adalah 0,42 .

Variabel kinerja auditor memiliki nilai minimum sebesar 3,20 dan nilai maksimum sebesar 5,00 dengan nilai rata-rata sebesar 4,11. Nilai rata-rata sebesar 4,11 menunjukkan bahwa responden dalam menjawab pernyataan pada kuesioner cenderung merasa setuju, artinya kinerja auditor cenderung tinggi. Standar deviasi pada variabel kinerja auditor adalah sebesar 0,46. Hal ini menunjukkan bahwa standar penyimpangan data terhadap nilai rata-ratanya adalah 0,46 .

Pengujian data dalam penelitian ini menggunakan teknik analisis regresi moderasi. Perhitungan koefisien regresi moderasi dilakukan dengan analisis regresi melalui software SPSS 18.0 for Windows, diperoleh hasil yang ditunjukan pada Tabel 3 berikut: 
Tabel 3.

Hasil Analisis Regresi Moderasi

\begin{tabular}{|c|c|c|c|c|c|}
\hline \multirow[t]{2}{*}{ Model } & \multicolumn{2}{|c|}{$\begin{array}{l}\text { Unstandardized } \\
\text { Coefficients }\end{array}$} & \multirow{2}{*}{$\begin{array}{l}\text { Standardized } \\
\text { Coefficients } \\
\text { Beta }\end{array}$} & \multirow[b]{2}{*}{$\mathbf{t}$} & \multirow[b]{2}{*}{ Sig. } \\
\hline & B & Std. Error & & & \\
\hline 1 (Constant) & 1.158 & .275 & & 4.213 & .000 \\
\hline Komitmen Organisasi & .144 & .054 & .155 & 2.640 & .012 \\
\hline Motivasi kerja & .124 & .050 & .144 & 2.489 & .017 \\
\hline Tindakan Supervisi & -.075 & .062 & -.070 & -1.202 & .236 \\
\hline Interaksi X1.X3 & .003 & .001 & .524 & 5.493 & .000 \\
\hline Interaksi X2.X3 & .002 & .001 & .320 & 3.141 & .003 \\
\hline R Square & & & & & 0,898 \\
\hline Adjusted R Square & & & & & 0,886 \\
\hline F Statistik & & & & & 74,030 \\
\hline Signifikansi & & & & & 0,000 \\
\hline
\end{tabular}

Sumber: Data diolah, 2018

Berdasarkan hasil analisis regresi moderasi seperti yang disajikan pada

Tabel 3, maka persamaan strukturalnya adalah sebagai berikut :

$$
Y=1,158+0,144 X_{1}+0,124 X_{2}-0,075 X_{3}+0,003 X_{1} \cdot X_{3}+0,002 X_{2} \cdot X_{3}
$$

Hasil uji memberikan hasil dimana diperoleh besarnya adjusted $\mathrm{R}^{2}$ (koefisien determinasi yang telah disesuaikan) pada Tabel 3 adalah 0,886. Ini berarti variasi kinerja auditor dapat dipengaruhi secara signifikan oleh variasi komitmen organisasi $\left(\mathrm{X}_{1}\right)$, motivasi kerja $\left(\mathrm{X}_{2}\right)$, tindakan supervisi $\left(\mathrm{X}_{3}\right)$, interaksi $\mathrm{X}_{1} \cdot \mathrm{X}_{3}$ dan interaksi $\mathrm{X}_{2} . \mathrm{X}_{3}$ sebesar 88,6 persen, sedangkan sisanya sebesar 11,4 persen dijelaskan oleh faktor-faktor lain yang tidak dijelaskan dalam model penelitian.

Hasil uji F (Ftest) pada Tabel 3 menunjukkan bahwa nilai signifikansi $\mathrm{P}$ value 0,000 yang lebih kecil dari $\alpha=0,05$, ini berarti model yang digunakan pada penelitian ini adalah layak. Hasil ini memberikan makna bahwa seluruh variabel independen mampu memprediksi atau menjelaskan fenomena kinerja auditor. Dengan kata lain komitmen organisasi $\left(\mathrm{X}_{1}\right)$, motivasi kerja $\left(\mathrm{X}_{2}\right)$, tindakan supervisi $\left(\mathrm{X}_{3}\right)$, interaksi komitmen organisasi dengan tindakan supervisi dan 
interaksi motivasi kerja dengan tindakan supervisi secara simultan berpengaruh signifikan terhadap kinerja auditor. Hal ini berarti model dapat digunakan untuk analisa lebih lanjut atau dengan kata lain model dapat digunakan untuk memproyeksikan karena hasil goodness of fitnya baik dengan nilai signifikansi $\mathrm{P}$ value 0,000 .

Variabel moderasi dapat diklasifikasikan menjadi 4 jenis. Masing-masing klasifikasi moderasi dapat diidentifikasi sebagaimana contoh berikut, jika $\mathrm{X}$ adalah variabel predictor, $\mathrm{Y}$ variabel terikat dan $\mathrm{M}$ variabel moderasi maka persamaan regresi yang dapat dibentuk sebagai berikut :

$$
\mathrm{Y}=\beta_{1} \mathrm{X}_{1}+\beta_{2} \mathrm{M}_{1}+\beta_{3} \mathrm{X}_{1} * \mathrm{M}_{1}
$$

Tabel 5.

Klasifikasi Variabel Moderasi

\begin{tabular}{cll}
\hline No. & \multicolumn{1}{c}{ Tipe Moderasi } & \multicolumn{1}{c}{ Koefisien } \\
\hline 1 & Pure Moderasi & $\mathrm{b}_{2}$ non significant \\
& & $\mathrm{b}_{3}$ significant \\
& Quasi Moderasi & $\mathrm{b}_{2}$ significant \\
& & $\mathrm{b}_{3}$ significant \\
& Homologiser Moderasi & $\mathrm{b}_{2}$ non significant \\
4 & Predictor Moderasi & $\mathrm{b}_{3}$ non significant \\
& & $\mathrm{b}_{2}$ significant \\
Sumber: Solimun, 2010 & $\mathrm{~b}_{3}$ non significant
\end{tabular}

Dalam penelitian ini kriteria pengujian untuk menjelaskan interpretasi pengaruh antar masing-masing variabel yakni jika nilai signifikansi $<0,05$ Hipotesis dalam penelitian ini diterima.

Berdasarkan hasil analisis pengaruh komitmen organisasi terhadap kinerja auditor diperoleh nilai signifikansi sebesar 0,012 dengan nilai koefisien regresi sebesar 0,144 yang berarti angka tersebut lebih kecil dari taraf nyata dalam penelitian ini, yaitu 0,050 yang mengidikasikan bahwa $\mathrm{H}_{1}$ diterima. Artinya komitmen organisasi berpengaruh positif dan signifikan pada kinerja auditor. 
Ida Ayu Mirah Kusuma Putri dan I Dewa Nyoman Badera. Pengaruh...

Hal tersebut menunjukkan bahwa komitmen organisasi merupakan konsistensi terhadap organisasi dan wujud keterikatan seseorang terhadap suatu pekerjaan atau organisasi tersebut. Melalui adanya suatu komitmen organisasi maka dapat menjadi dorongan bagi individu maupun organisasi untuk bekerja lebih baik sehingga dapat meningkatkan kinerjanya khususnya sebagai seorang auditor. Penelitian ini juga didukung oleh penelitian dari Lina (2017), Fernando et al (2005), Lawata (2011), Riezki (2015), Wijana (2015), Putri (2015), Alfianto dan Suryandari (2015).

Berdasarkan hasil analisis pengaruh motivasi kerja terhadap kinerja auditor diperoleh nilai signifikansi sebesar 0,017 dengan nilai koefisien regresi sebesar 0,124 yang berarti nilai signifikansi lebih kecil dari 0,050 mengindikasikan bahwa $\mathrm{H}_{2}$ diterima. Hasil ini mempunyai arti bahwa motivasi kerja berpengaruh positif dan signifikan terhadap kinerja auditor.

Hal tersebut menunjukkan bahwa motivasi kerja seorang auditor tinggi dalam melaksanakan tugas dan tanggungjawabnya. Motivasi kerja merupakan dorongan perilaku individu untuk bekerja dan memiliki tingkat upaya yang tinggi dalam mencapai kinerja yang baik. Sebagai seorang auditor motivasi sangat diperlukan dalam menyelesaikan tugasnya karena perilaku tersebut dapat menumbuhkan semangat tinggi dalam mengerjakan tugas dan tanggungjawabnya. Penelitian ini juga didukung oleh penelitian Daryatmi (2005), Syamsul (2010), Dalmy (2009), Albar (2009) dan Dwilita (2007).

Hasil analisis regresi moderasi menunjukkan bahwa nilai koefisien regresi komitmen organisasi $\left(\beta_{1}\right)$ positif sebesar 0,144 dengan nilai signifikansi sebesar 
0,012 dan nilai koefisien regresi variabel interaksi $X_{1} \cdot X_{3}\left(\beta_{4}\right)$ positif sebesar 0,003 dengan nilai signifikansi 0,000 , maka hal tersebut menunjukkan adanya hubungan searah karena sama-sama memiliki nilai koefisien yang positif, sehingga dapat disimpulkan bahwa variabel tindakan supervisi merupakan variabel moderasi yang memperkuat pengaruh komitmen organisasi pada kinerja auditor.

Hal ini berarti adanya tindakan supervisi memperkuat komitmen auditor di organisasi tersebut. Tindakan supervisi dapat mempengaruhi individu maupun organisasi dalam melaksanakan tugasnya. Tindakan supervisi yang dapat memberikan feedback dan supervisor yang memiliki peran yang baik pada bawahannya serta dapat menumbuhkan hubungan yang baik antara atasan dan bawahan akan mendorong tercapainya kesuksesan. Hal tersebut menunjukkan bahwa pada dasarnya komitmen organisasi itu adalah suatu keadaan yang menunjukkan bahwa seorang auditor memiliki hubungan baik dengan organisasi itu melalui adanya tujuan yang sama dengan organisasi tersebut dan hubungan yang baik antara senior dan junior. Tindakan supervisi yang memiliki tujuan baik dan dapat mempengaruhi auditor agar para auditor tetap pada jalurnya dan dapat dimanfaatkan dengan sebaik-baiknya oleh auditor, hal tersebut dapat membuat kinerja auditor meningkat karena auditor merasa ada hubungan baik dengan pimpinannya sehingga memiliki komitmen yang sama. Tindakan supervisi yang dapat memberikan unsur loyalitas kepada auditor sangat berpengaruh terhadap KAP, sehingga dengan adanya komitmen organisasi akan menimbulkan rasa ikut memiliki bagi auditor terhadap organisasi. Tindakan supervisi yang menanamkan rasa kebersamaan untuk memajukan organisasi, meningkatkan komitmen 
Ida Ayu Mirah Kusuma Putri dan I Dewa Nyoman Badera. Pengaruh...

kontinuan dan komitmen afektif sangat berdampak pada kinerja auditor Kantor Akuntan Publik.

Hasil analisis regresi moderasi menunjukkan bahwa nilai koefisien regresi motivasi kerja $\left(\beta_{2}\right)$ positif sebesar 0,124 dengan nilai signifikansi sebesar 0,017 dan nilai koefisien regresi variabel interaksi $X_{2} \cdot X_{3}\left(\beta_{5}\right)$ positif sebesar 0,002 dengan nilai signifikansi 0,003 , maka hal tersebut menunjukkan adanya hubungan yang searah karena sama-sama memiliki nilai koefisien yang positif, sehingga dapat disimpulkan bahwa variabel tindakan supervisi merupakan variabel moderasi yang memperkuat pengaruh motivasi kerja pada kinerja auditor.

Hal tersebut menunjukkan bahwa tindakan supervisi yang dapat mempengaruhi bawahannya dengan memberikan motivasi, masukan-masukan dan mengevaluasi pekerjaan karyawan maka dapat memberikan kesan baik kepada bawahannya. Tindakan supervisi yang dapat menunjukkan sikap kepemimpinan yang kuat dapat memotivasi kerja seorang auditor dalam menghasilkan kinerja yang baik. Supervisi dalam bentuk mentoring atau pelatihan secara kontinyu dapat menumbuhkan motivasi kerja sehingga dapat mencapai kinerja yang diharapkan. Dengan adanya supervisi dari pimpinan diharapkan dapat menciptakan kondisi kerja yang mendorong tercapainya kesuksesan. Tindakan supervisi yang partisipatif akan juga akan menumbuhkan motivasi kerja khususnya instriksik motivation sehingga secara tidak langsung memacu prestasi kerja atau kinerja auditor dalam melaksanakan tugasnya. Dengan kata lain pengaruh dari tindakan supervisi dengan memberikan motivasi kerja dapat mendorong auditor untuk mencapai kinerja yang diharapkan. 
Hasil penelitian ini diharapkan mampu memberikan bukti empiris tentang pengaruh komitmen organisasi dan motivasi kerja terhadap kinerja auditor dengan tindakan supervise sebagai variabel moderasi. Hasil uji dalam penelitian ini ditemukan bahwa variabel komitmen organisasi berpengaruh positif dan signifikan terhadap kinerja auditor, motivasi kerja berpengaruh positif dan signifikan terhadap kinerja auditor, tindakan supervisi memperkuat pengaruh komitmen organisasi terhadap kinerja auditor dan tindakan supervisi memperkuat pengaruh motivasi kerja terhadap kinerja auditor. Dalam hal ini teori atribusi mendukung penelitian ini karena penelitian ini berfokus pada faktor-faktor yang dapat mempengaruhi kinerja auditor, khususnya pada karakteristik pribadi auditor itu sendiri. Auditor yang memiliki komitmen organisasi dan motivasi kerja yang tinggi dan disertai dengan pentingnya peran supervisor dalam memberikan bimbingan kepada akuntan pemula dapat meningkatkan kinerja auditor, sehingga menghasilkan kinerja yang baik.

Hasil penelitian ini dapat dijadikan sebagai bahan pertimbangan auditor dalam meningkatkan kinerjanya dan sebagai pertimbangan dalam mengambil kebijakan dalam melaksanakan tugasnya dengan mempertahankan sikap komitmen organisasi dan motivasi kerja dengan didukung adanya tindakan supervisi.

\section{SIMPULAN}

Variabel komitmen organisasi berpengaruh positif dan signifikan terhadap kinerja auditor di Kantor Akuntan Publik Provinsi Bali. Ini menunjukkan bahwa 
Ida Ayu Mirah Kusuma Putri dan I Dewa Nyoman Badera. Pengaruh...

komitmen organisasi yang tinggi akan meningkatkan kinerja auditor. Komitmen seorang auditor dapat menjadi dorongan bagi auditor itu sendiri untuk bekerja lebih baik.

Variabel motivasi kerja berpengaruh positif dan signifikan terhadap kinerja auditor di Kantor Akuntan Publik di Provinsi Bali. Ini menunjukkan bawah motivasi kerja yang tinggi akan meningkatkan kinerja auditor. Motivasi sangat diperlukan seorang auditor karena perilaku tersebut dapat menumbuhkan semangat yang tinggi dalam mengerjakan tugas dan tanggungjawabnya maka hal tersebut dapat menghasilkan kinerja auditor yang baik.

Tindakan supervisi memperkuat pengaruh komitmen organisasi terhadap kinerja auditor di Kantor Akuntan Publik Provinsi Bali. Hal ini berarti tindakan supervisi merupakan tindakan yang dapat mempengaruhi auditor dalam mengerjakan tugasnya melalui pemberian saran dan hubungan yang baik antara atasan dan bawahan.

Tindakan supervisi memperkuat pengaruh motivasi kerja terhadap kinerja auditor di Kantor Akuntan Publik Provinsi Bali. Hal ini berarti tindakan supervisi yang dapat memberikan masukan-masukan, memberikan kesan yang baik, dan memotivasi bawahannya dapat memberikan motivasi bagi auditor untuk memberikan hasil kerja yang maksimal.

Bagi Kantor Akuntan Publik (KAP), bagi auditor yang bekerja pada Kantor Akuntan Publik di Provinsi Bali disarankan agar dapat turut serta dalam memberikan peningkatan kinerja auditor dalam menjalankan prosedur audit juga diharapkan untuk turut berpartisipasi memberikan usulan kepada supervisor 
mengenai prosedur audit dan dapat menyelesaikan tugas pemeriksaan dengan motivasi yang tinggi untuk memberikan hasil kerja yang baik.

Bagi penelitian selanjutnya, penelitian selanjutnya disarankan agar menambahkan variabel lain yang dapat mempengaruhi kinerja auditor. Disarankan juga untuk mempertimbangkan faktor lain yang dapat menjadi variabel moderasi yang memperkuat atau memperlemah pengaruh variabel bebas terhadap variabel kinerja auditor.

\section{REFERENSI}

Agung, A., \& Dea, S. (2018). Pengaruh Profesionalisme , Pengalaman Kerja , Konflik Peran dan Ketidakjelasan Peran Pada Kinerja Auditor KAP di Bali Fakultas Ekonomi dan Bisnis Universitas Udayana ( Unud ), Bali, 23, 9821007.

Agustini, Lina dan Dwirandra. (2017). E-Jurnal Akuntansi Universitas Udayana pada kinerja auditor dengan tindakan supervisi sebagai variabel moderasi Fakultas Ekonomi dan Bisnis Universitas Udayana ( Unud ), Bali , Ind. Jurnal Akuntansi Univeristas Udayana, 21, 1430-1459.

Akbar, Z. (2009). Pengaruh Tingkat Pendidikan, Pendidikan Berkelanjutan, Komitmen Organisasi, Sistem Reward, Pengalaman Dan Motivasi Auditor Terhadap Kinerja Auditor Inspektorat Provinsi Sumatera Utara, 2009. Thesis Universitas Sumatera Utara.

Al-khaddash, H., Nawas, R. Al, \& Ramadan, A. (2013). Factors affecting the quality of Auditing: The Case of Jordanian Commercial Banks. International Journal of Business and Social Science, 4(11), 206-222.

Aranya, Nissim and Ferris, Kenneth R. (n.d.). A Reexamination of Accountants' Organizational-Professional Conflict.

Bahri, S. (2010). Pengaruh Motivasi, Tindakan Supervisi, Dan Budaya Organisasi Terhadap Kinerja Auditor Junior, (105082002686). Retrieved from http://repository.uinjkt.ac.id/dspace/handle/123456789/21112

Dali, N., \& Mas'ud, A. (2014). The Impact of Professionalism, Locus of Control, and Job Satisfaction on Auditors' Performance: Indonesian Evidence. 
Ida Ayu Mirah Kusuma Putri dan I Dewa Nyoman Badera. Pengaruh...

International Journal of Business and Management Invention, 3(10), 63-73.

Dalmy, D. (2009). kinerja auditor dan reward sebagai variabel moderasing pada Untuk Memperoleh Gelar Magister Sains dalam Program Studi Ilmu Akuntansi pada Sekolah Pascasarjana Universitas Sumatera Utara.

Fanani, Z., Afriana Hanif, R., \& Subroto, B. (2008). Pengaruh Struktur Audit, Konflik Peran, Dan Ketidakjelasan Peran Terhadap Kinerja Auditor. Jurnal Akuntansi Dan Keuangan Indonesia, 5(2), 139-155. https://doi.org/10.1017/CBO9781107415324.004

Goldwasser. (1993). The Plaintiffs' Bar Discusses Auditor Performance. Journal of CPA New York State Society of Certified Public Accountants, 63(10), 4853.

Hanna, E., \& Firnanti, F. (2013). Faktor-Faktor yang Memengaruhi Kinerja Auditor. Jurnal Bisnis Dan Akuntansi, 15(1), 1410-9875.

Kalbers, L. P., \& Fogarty, T. J. (1995). Professionalism and Its Consequences: A Study of Internal Auditors. Auditing: A Journal of Practice \& Theory, 14(1), 64-86. Retrieved

from http://search.ebscohost.com/login.aspx?direct=true \&db=bth\&AN=95092647 $93 \&$ site $=$ eds-live $\&$ authtype $=$ uid

Lawalata, J., Sadi, D., \& Mediaty. (2010). Pengaruh Independensi Auditor, komitmen Organisasi, gaya Kepemimpinan dan Budaya Orgnisasi terhadap Kinerja Auditor. Jurnal Universitas Hasanudin, 0-9.

Robbins, S. P., Judge T. A. (2007), "Perilaku Organisasi jilid 2 Edisi ke 12", Penerbit Salemba Empat.

Robbins, Stephen. (2008). Perilaku Organisasi Edisi Keduabelas. Salemba Empat: Jakarta.

Sari Kartika, Diah Ni Wayan. (2016). kepuasan kerja sebagai pemediasi pengaruh tindakan supervisi dan komitmen organisasi pada kinerja auditor. E-Jurnal Akuntansi Universitas Udayana, 15, 1145-1171.

Siahaan, V. D. (2010). Organisasi Dalam Upaya Meningkatkan Kinerja Auditor ( Studi Pada Kantor Perwakilan Bpk-Ri Provinsi Aceh ). Jurnal T, 3(1), 1028.

Trisnaningsih, S. R. I. (n.d.). Independensi auditor dan komitmen organisasi sebagai mediasi pengaruh pemahaman, 1-56. 